\title{
SECULAR TRENDS IN LATE FOETAL DEATHS, NEONATAL MORTALITY, AND BIRTH WEIGHT IN ENGLAND AND WALES, 1956-65
}

BY

\author{
J. R. ASHFORD, M.A., Ph.D. \\ Professor of Statistics, University of Exeter
}

J. G. FRYER, Ph.D.

Lecturer in Mathematical Statistics, University of Exeter

AND

F. S. W. BRIMBLECOMBE, M.D., F.R.C.P., D.C.H.

Paediatrician, Exeter City Hospital, and Postgraduate Medical Institute, University of Exeter

During recent years the Annual Reports of the Ministry of Health have shown a steady reduction in perinatal mortality in England and Wales. A comparison of trends in infant and childhood mortality in various countries during the decade 1950-59 (Hunt and Goldstein, 1961) reveals a fall in neonatal mortality in the United Kingdom of about $18 \%$. Greater proportional reductions in neonatal mortality were recorded in Japan (38\%), West Germany ( $31 \%$ ), Finland $(31 \%)$, the Netherlands $(28 \%)$, Luxembourg $(26 \%)$, and Canada $(23 \%)$. On the other hand, the reduction in neonatal mortality in the United States during the same 10year period was only about $10 \%$. Comparable figures, which include late foetal deaths (stillbirths) for the five-year period $1955-60$, show a proportionate reduction in late foetal and neonatal deaths of $9 \%$ in the United Kingdom, compared with $18 \%$ in West Germany and $8 \%$ in the United States. In general, the greatest progress has been recorded in countries with the highest mortality levels at the beginning of the period and vice versa.

Within a given population the factors which increase the risk of perinatal death include low socio-economic status, short stature, advanced parity, and advanced age of mother (Duncan, Baird, and Thomson, 1952). Low birth weight is also very important (Brimblecombe, Ashford and Fryer, 1968). Temporal variations in all these factors, together with improvements in the standards of medical care, are likely to be reflected in changes in perinatal and neonatal mortality rates and hence to throw light upon the underlying causes of late foetal and neonatal deaths.
The present paper is concerned essentially with trends in perinatal and neonatal mortality in England and Wales during the 10-year period 1956-65. This study has been carried out with particular reference to the effect of variations in birth weight $\vec{\bullet}$ distribution and forms part of a long-term investic of gation of the biology of low birth weight.

\section{SOURCES OF MATERIAL}

The primary source of information for this study was the annual return L.H.S. 27/1, made by each local authority in England and Wales to the Ministry of Health during the years 1956-65 inclusive. The format of the data collected changed once during this period, between 1962 and 1963. Since 1963 the returns have shown for infants in each birth weight group (1,000 g. or less, 1,0011,500 g., 1,501-2,000 g., 2,001-2,250 g., and 2,251$2,500 \mathrm{~g}$.) the numbers of late foetal deaths and live births together with neonatal deaths within 24 hours of birth, within 1-6 days and within 7-28 days. No specific information is given about infants with birth weights above 2,500 g., although the total numbers of late foetal deaths and live births in the local authority area are recorded. The records for the period 1956-62 provide less detailed information in terms of birth weight, in that all births of less than $1,500 \mathrm{~g}$. are grouped together. Furthermore, the neonatal deaths are recorded for the periods less than 24 hours and less than 28 days only, but not for less than 7 days.

The second source of information was the Registrar-General's Statistical Reviews of England and Wales, which show the total number of late 
foetal deaths and live births in each local authority area, together with the numbers of neonatal deaths within 28 days of birth and (since 1957) within 7 days of birth. Both sources of data are adjusted to take account of transfers into and out of each particular area. Since the two sets of data showed minor discrepancies we have used the L.H.S. 27/1 information wherever possible to preserve the internal consistency of the analysis.

To examine the main trends the results have been summarized as follows:

(a) Eleven standard regions were used by the Registrar-General prior to 1965 , and these are for the most part defined by local authority boundaries. Where a local authority overlaps more than one region, the births in that area have been assigned to the region which contains the greatest proportion of its population. As a result of the local authority boundary changes, which gave rise in 1965 to the formation of Greater London, the geographical composition of the Eastern, London and SouthEastern, and Southern regions is slightly different from that adopted for previous years, although the areas covered are very similar.

(b) Local authorities designated as county boroughs, which are for the most part urban areas, have been contrasted with all the remaining local authorities which are more rural in character. In this analysis London A.C. and the new London boroughs are regarded as county boroughs.

(c) The Registrar-General defines six conurbations in England and Wales. The particular county boroughs which form the central and thus more urban parts of each of these standard conurbations have been separately identified. These are contrasted with the group of local authorities of which part, but not the whole, is included in one or other of the Registrar-General's six conurbations (part-conurbation) and with the remaining local authorities which include no part of a standard conurbation (non-conurbation).

\section{Distribution of BiRTH Weight}

In a study of perinatal mortality in England and Wales during the three years 1963-65, Brimblecombe et al. (1968) have shown that much of the variation between different parts of the country may be explained in terms of the corresponding variation in the distribution of birth weights. The areas with the greater proportions of low birth weight infants have the higher perinatal mortality and vice versa. By the same token, birth weight is likely to bear an equally close relation to temporal trends in mortality within the same population.

The distribution of birth weights up to $2,501 \mathrm{~g}$.
TABLE I

SECULAR TRENDS IN BIRTH WEIGHT DISTRIBUTION (RATE PER 1,000 TOTAL BIRTHS ENGLAND AND WALES, 1956-65)

\begin{tabular}{c|c|c|c|c|c}
\hline & \multicolumn{5}{|c}{ Birth Weight (8.) } \\
\cline { 2 - 6 } Year & $<1501$ & 2000 & $2001-$ & $2251-$ & \\
& & 250 & 2500 & $<2501$ \\
\hline 1956 & 12.8 & 15.4 & 15.0 & 35.1 & 78.3 \\
1957 & 13.2 & 15.6 & 14.9 & 36.1 & 79.8 \\
1958 & 12.7 & 15.3 & 14.8 & 35.7 & 78.4 \\
1959 & 12.5 & 14.5 & 14.6 & 35.2 & 76.8 \\
1960 & 12.3 & 14.7 & 14.5 & 34.9 & 76.4 \\
1961 & 12.5 & 14.7 & 14.5 & 34.8 & 76.5 \\
1962 & 12.0 & 14.2 & 14.7 & 34.8 & 75.7 \\
1963 & 11.8 & 14.4 & 14.8 & 33.5 & 74.5 \\
1964 & 11.6 & 13.6 & 14.0 & 32.7 & 71.9 \\
1965 & 11.1 & 13.6 & 13.9 & 33.2 & 71.7 \\
\hline
\end{tabular}

per 1,000 total births for each successive year between 1956 and 1965 is shown in Table I. For the last nine years of this 10 -year period there is a general tendency for the proportion of births in each of the birth weight groups below 2,501 g. to decline year by year. The proportion of births of less than $2,501 \mathrm{~g}$. fell from 79.8 per 1,000 in 1957 to 71.7 per 1,000 in 1965 . The corresponding figures for births of less than $1,501 \mathrm{~g}$. were 13.2 in 1957 and 11.1 in 1965 . When the cumulative distributions of birth weight are plotted on a probit scale, the points corresponding to birth weights of up to 2,250 g. define a sequence of parallel straight lines displaced slightly to the right with each successive year. This corresponds to a progressive increase year by year in the mean of the secondary component of the birth weight distribution (Brimblecombe et al., 1968).

The proportions of late foetal deaths and live births of less than 2,501 g. birth weight per 1,000 total births in the county boroughs and in all other local authorities are shown in Table II. The marked differences between the two types of local authority noted in the analysis of the data for 1963-65 persist over the whole 10-year period. Indeed, the excess

TABLE II

COMPARISON OF SECULAR TRENDS IN BIRTH WEIGHT DISTRIBUTION IN COUNTY BOROUGHS AND ALL OTHER LOCAL AUTHORITIES (BIRTHS OF WEIGHT LESS THAN 2,501 g. PER 1,000 TOTAL BIRTHS, ENGLAND AND WALES, 1956-65)

\begin{tabular}{c|c|c}
\hline Year & $\begin{array}{c}\text { County } \\
\text { Boroughs } \\
\text { (including } \\
\text { London) }\end{array}$ & $\begin{array}{c}\text { All } \\
\text { other } \\
\text { Local } \\
\text { Authorities }\end{array}$ \\
\hline 1956 & 85.2 & 73.7 \\
1957 & 86.4 & 75.6 \\
1958 & 86.7 & 73.2 \\
1959 & 84.9 & 71.8 \\
1960 & 83.7 & 71.9 \\
1961 & 84.3 & 71.7 \\
1962 & 83.8 & 70.7 \\
1963 & 84.0 & 68.9 \\
1964 & 80.1 & 67.2 \\
1965 & 78.9 & 65.8 \\
\hline
\end{tabular}


of infants of less than $2,501 \mathrm{~g}$. birth weight in the county boroughs as compared with all other local authorities increased from 11.5 per 1,000 in 1956 to $13 \cdot 1$ per 1,000 in 1965 . The temporal variations in both types of community show a similar pattern, although the main changes have tended to occur about one year later in the county boroughs than in the other local authorities.

When the secular trends in birth weight distribution in the standard regions and conurbations as defined above were examined it was found that in most cases the highest proportions of low weight births were recorded in 1957 or 1958 and the lowest proportions in 1964 and 1965. The same general pattern of geographical variation present in the results for 1963-65 persists throughout the whole 10-year period, with the greatest proportion of low weight births in the more urban parts of the northern, midland, and South Wales regions.

The patterns of variation from year to year within the different regions and conurbations follow no consistent trend; furthermore, some regions show a wider fluctuation than others. Nevertheless some comparison covering the 10 -year period is called for and for this reason a simple standard measure of change has been calculated. Denoting the average for the years 1956-58 by $A_{1}$ and the average for $1963-65$ by $A_{2}$, the quantity

$$
T=\frac{5}{4}\left(A_{1}-A_{2}\right)
$$

has been used as a measure of absolute change over the 10 years. Positive values of this measure indicate a fall in the proportion of low birth weight infants and negative values a rise.

Two main points emerge from the results for the standard regions, which appear in Table III. First, the greatest changes have taken place for the most part in the regions with the highest proportion of low weight births at the beginning of the period and this has resulted in some narrowing of the difference between the south and the north, midlands and South Wales. Secondly, the measure of change is larger for areas other than county boroughs than for the county boroughs, despite the fact that the former had a consistently lower proportion of low weight births in 1956. A further feature is the fact that a negative measure of change was reeorded for the Southern region county boroughs, which may be due to some extent to the change in regional boundaries in 1965. Table IV shows the measure of trend of the birth weight distribution calculated for the standard conurbations as defined above. No clear geographical pattern emerges; indeed the most remarkable feature of the
TABLE III

MEASURE OF TREND (T) IN BIRTH WEIGHT AND MORTALITY IN THE STANDARD REGIONS, ENGLAND AND WALES, 1956-65

\begin{tabular}{|c|c|c|c|c|}
\hline \multirow[b]{2}{*}{ Region } & \multicolumn{2}{|c|}{$\begin{array}{l}\text { County Boroughs } \\
\text { (including London) }\end{array}$} & \multicolumn{2}{|c|}{$\begin{array}{l}\text { All other Local } \\
\text { Authorities }\end{array}$} \\
\hline & $\begin{array}{c}\text { Birth } \\
\text { Weight } \\
\text { (propor- } \\
\text { tion } \\
<2,501 \text { g.) }\end{array}$ & $\begin{array}{c}\text { Mortality } \\
\text { Rate }\end{array}$ & $\begin{array}{c}\text { Birth } \\
\text { Weight } \\
\text { (propor- } \\
\text { tion } \\
<2,501 \text { g.) }\end{array}$ & $\begin{array}{l}\text { Mortality } \\
\text { Rate }\end{array}$ \\
\hline 1. Northern & $12 \cdot 9$ & $10 \cdot 9$ & $10 \cdot 4$ & $9 \cdot 6$ \\
\hline 2. Ridings & $8 \cdot 1$ & $9 \cdot 4$ & $9 \cdot 5$ & $11 \cdot 4$ \\
\hline Western & $9 \cdot 4$ & $11 \cdot 0$ & $12 \cdot 4$ & $12 \cdot 0$ \\
\hline $\begin{array}{l}\text { Midland } \\
\text { 5. Midland } \\
6 . \text { Eastern }\end{array}$ & $\begin{array}{l}6 \cdot 7 \\
2 \cdot 9 \\
1 \cdot 4\end{array}$ & $\begin{array}{r}9 \cdot 4 \\
107 \\
5 \cdot 9\end{array}$ & $\begin{array}{r}15 \cdot 6 \\
11 \cdot 1 \\
4 \cdot 7\end{array}$ & $\begin{array}{r}13.9 \\
11.9 \\
9.5\end{array}$ \\
\hline 8. Southern & $\begin{array}{r}2 \cdot 4 \\
-7 \cdot 4\end{array}$ & $\begin{array}{l}7 \cdot 6 \\
9 \cdot 6\end{array}$ & $\begin{array}{l}7 \cdot 7 \\
1 \cdot 1\end{array}$ & $\begin{array}{l}7 \cdot 1 \\
8 \cdot 0\end{array}$ \\
\hline $\begin{array}{l}\text { Western } \\
\text { 10. Wales I } \\
\text { 11. Wales II }\end{array}$ & $\begin{array}{r}2: 9 \\
11 \cdot 5 \\
\end{array}$ & $\begin{array}{r}9 \cdot 0 \\
17 \cdot 0 \\
\end{array}$ & $\begin{array}{r}4 \cdot 2 \\
12 \cdot 1 \\
18 \cdot 0\end{array}$ & $\begin{array}{l}11 \cdot 0 \\
12 \cdot 6 \\
14 \cdot 2\end{array}$ \\
\hline
\end{tabular}

TABLE IV

MEASURE OF TREND (T) IN BIRTH WEIGHT AND MORTALITY IN THE STANDARD CONURBATIONS, ENGLAND AND WALES, 1956-65

\begin{tabular}{|c|c|c|}
\hline Rates & $\begin{array}{c}\text { Birth Weight } \\
\text { (proportion } \\
<2501 \text { g.) }\end{array}$ & $\begin{array}{c}\text { Mortality } \\
\text { Rate }\end{array}$ \\
\hline $\begin{array}{l}\text { 1. No part } \\
\text { 2. Some part } \\
\text { 3. Tyneside } \\
\text { 4. West Yorkshire } \\
\text { 5. South East Lancashire } \\
\text { 6. Merseyside } \\
\text { 7. West Midlands } \\
\text { 8. Greater London }\end{array}$ & $\begin{array}{r}10 \cdot 0 \\
7.7 \\
2.9 \\
6.5 \\
1.4 \\
15 \cdot 1 \\
2.4 \\
0 \cdot 1\end{array}$ & $\begin{array}{r}12.0 \\
9 \cdot 4 \\
10 \cdot 7 \\
7 \cdot 9 \\
8 \cdot 1 \\
12.2 \\
9 \cdot 6 \\
6.5\end{array}$ \\
\hline
\end{tabular}

data is the contrast between Merseyside and its neighbour, South East Lancashire.

The secular variations in the birth weight distributions of the late foetal deaths and live births $\frac{\rho}{\square}$ separately and in the sum of the two are illustrated in Figure 1. During the period under review the proportion of live births of less than 2,501 g. in the whole of England and Wales was highest in 1957, ₹ fell slightly between 1957 and 1959, remained vir- 윽 tually constant between 1959 and 1962, and fell $>$ again between 1963 and 1964 . On the other hand, the proportion of late foetal deaths of less than $N$ 2,501 g. increased between 1956 and 1963 and fell slightly in 1964. When live births and late foetal $N$ deaths are taken together the combined results follow a similar trend to that of the live births alone.

\section{MORTALITY}

Because the data for the years $1956-62$ provide $\frac{T}{0}$ no information about mortality within the first 


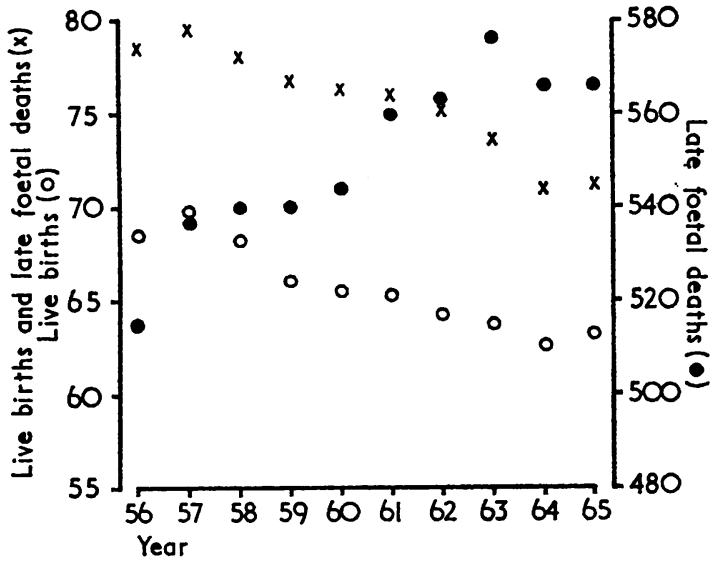

Fig. 1. Secular variations in births of 2,501 g. or less per 1,000 total births for (i) late foetal deaths, (ii) live births, and (iii) live births and late foetal deaths, England and Wales 1956-65.

seven days of life, it was not possible to study the secular trends in terms of the international definition of perinatal mortality. Separate analyses have therefore been carried out of late foetal deaths, of deaths within 24 hours of birth, and of deaths within 28 days of birth. In addition, the figures for late foetal deaths and deaths within 28 days have been combined to provide a measure of total mortality. Studies of the data collected during the period 1963-65 suggest that this over-estimates perinatal mortality by about $6.4 \%$ for all birth weights and by about $3 \cdot 5 \%$ for births of less than 2,501 g. The changes over the 10-year period are illustrated in Table $\mathrm{V}$ which shows the numbers of late foetal deaths and deaths within 28 days per 1,000 total births in the various weight groups. For all birth weight groups the mortality rates as defined above fell steadily year by year, from 39.1 in 1956 to 28.7 in 1965 . The relative improvement in mortality experience is closely related to birth weight. In comparison with 1956 figures the reduction in

TABLE V

SECULAR TRENDS IN LATE FOETAL DEATHS AND NEONATAL DEATHS PER 1,000 BIRTHS, ENGLAND AND WALES, $1956-65$

\begin{tabular}{|c|c|c|c|c|c|c|c|}
\hline \multirow[b]{2}{*}{ Year } & \multicolumn{7}{|c|}{ Weight Group (g.) } \\
\hline & $<1500$ & $\begin{array}{l}1501- \\
2000\end{array}$ & $\begin{array}{l}2001- \\
2250\end{array}$ & $\begin{array}{l}2251- \\
2500\end{array}$ & $<2501$ & $\begin{array}{l}\text { Over } \\
2500\end{array}$ & All \\
\hline $\begin{array}{l}1956 \\
1957 \\
1958 \\
1959 \\
1960 \\
1961 \\
1962 \\
1963 \\
1964 \\
1965\end{array}$ & $\begin{array}{l}801 \\
801 \\
804 \\
795 \\
796 \\
784 \\
790 \\
768 \\
762 \\
756\end{array}$ & $\begin{array}{l}353 \\
348 \\
347 \\
354 \\
332 \\
331 \\
321 \\
319 \\
311 \\
306\end{array}$ & $\begin{array}{l}163 \\
156 \\
156 \\
152 \\
150 \\
146 \\
140 \\
130 \\
136 \\
128\end{array}$ & $\begin{array}{l}91.6 \\
88.0 \\
89.5 \\
84.3 \\
81.4 \\
80.3 \\
76.8 \\
73.9 \\
69.7 \\
68.7\end{array}$ & $\begin{array}{l}273 \\
269 \\
267 \\
264 \\
257 \\
256 \\
248 \\
243 \\
239 \\
231\end{array}$ & $\begin{array}{l}19.3 \\
18.0 \\
17.3 \\
16.7 \\
16.1 \\
15.2 \\
15.0 \\
13.9 \\
13.6 \\
13.1\end{array}$ & $\begin{array}{l}39 \cdot 1 \\
38 \cdot 1 \\
37.0 \\
35.7 \\
34.6 \\
33.6 \\
32.6 \\
30.9 \\
29.8 \\
28.7\end{array}$ \\
\hline
\end{tabular}

mortality in 1965 was about $32 \%$ for the infants of birth weight over 2,500 g., $25 \%, 13 \%$, and $6 \%$ for the groups with birth weights 2,251-2,500 g., 2,001-2,250 g., 1,501-2,000 g., and less than 1,501 g. respectively, with an overall average of about $26 \%$.

In their study of perinatal mortality in England and Wales between 1963 and 1965, Brimblecombe et al. (1968) have shown that the relation between perinatal mortality and birth weight among the low weight births is linear when mortality is plotted on a probit scale. When the corresponding graph is plotted for the mortality data for each successive year (1956-65), the points corresponding to birth weights of up to $2,250 \mathrm{~g}$. define a sequence of parallel straight lines displaced progressively to the left with each successive year. This is so for both the county boroughs and the other local authorities. Thus the apparent differential improvement in mortality experience in terms of birth weight may, in fact, be regarded as the result of constant displacement in the mortality-birth weight response line.

The secular variations in the mortality rates of the county boroughs and other local authorities are shown in Table VI. For all birth weight groups

TABLe VI

SECULAR TRENDS IN LATE FOETAL DEATHS AND NEONATAL DEATHS PER 1,000 TOTAL BIRTHS IN COUNTY BOROUGHS AND ALL OTHER LOCAL AUTHORITIES, ENGLAND AND WALES, 1956-65

\begin{tabular}{|c|c|c|c|c|c|c|}
\hline \multirow{3}{*}{ Year } & \multirow{2}{*}{\multicolumn{3}{|c|}{$\begin{array}{c}\begin{array}{c}\text { County Boroughs } \\
\text { (including London) }\end{array} \\
\begin{array}{c}\text { Birth } \\
\text { Weight } \\
\text { (g.) }\end{array} \\
\end{array}$}} & \multirow{2}{*}{\multicolumn{3}{|c|}{\begin{tabular}{|c|}
$\begin{array}{c}\text { All Other Local } \\
\text { Authorities }\end{array}$ \\
$\begin{array}{c}\text { Birth } \\
\text { Weight } \\
\text { (g.) }\end{array}$ \\
\end{tabular}}} \\
\hline & & & & & & \\
\hline & $<2501$ & $\begin{array}{l}\text { Over } \\
2500\end{array}$ & All & $<2501$ & $\begin{array}{l}\text { Over } \\
2500\end{array}$ & All \\
\hline $\begin{array}{l}1956 \\
1957 \\
1958 \\
1959 \\
1960 \\
1961 \\
1962 \\
1963 \\
1964 \\
1965\end{array}$ & $\begin{array}{l}275 \\
269 \\
268 \\
234 \\
254 \\
254 \\
243 \\
235 \\
234 \\
222\end{array}$ & $\begin{array}{l}18.8 \\
17.8 \\
17.3 \\
16.7 \\
16.4 \\
16.2 \\
15.1 \\
14.6 \\
14.2 \\
13.7\end{array}$ & $\begin{array}{l}40 \cdot 6 \\
39 \cdot 5 \\
39 \cdot 1 \\
37.7 \\
36 \cdot 3 \\
36 \cdot 2 \\
34.2 \\
33.1 \\
31.8 \\
30.2\end{array}$ & $\begin{array}{l}271 \\
269 \\
267 \\
264 \\
260 \\
257 \\
252 \\
248 \\
243 \\
240\end{array}$ & $\begin{array}{l}19.6 \\
18.2 \\
17.4 \\
16.8 \\
16.0 \\
14.5 \\
14.9 \\
13.4 \\
13.2 \\
12.6\end{array}$ & $\begin{array}{l}38.2 \\
37.2 \\
35.6 \\
34.5 \\
33.5 \\
31.9 \\
31.6 \\
29.6 \\
28.7 \\
27.5\end{array}$ \\
\hline
\end{tabular}

below 2,501 g. the two sets of results follow a similar pattern to that of the combined data and for this reason the figures for all birth weights below 2,501 g. have been taken together. During the period 1956-59 the mortality rates for infants of less than $2,501 \mathrm{~g}$. birth weight in the county boroughs and the other local authorities are in close agreement. After 1959, however, the mortality of the low birth weight infants is lower in the county boroughs. The results for infants of birth weight 
greater than $2,500 \mathrm{~g}$. present a contrasting pattern in that there is a higher mortality in the county boroughs after 1959. The mortality figures for all birth weights reflect the differences in birth weight distribution noted previously, in that the mortality rate in the county boroughs was at least 2 per 1,000 higher than that in the other local authorities in each successive year.

The variations in mortality between the county boroughs and the other local authorities in each of the standard regions were also examined. In most regions the highest mortality rates occurred in 1956-57 and the lowest in 1964-65. For each region the overall mortality figure for county boroughs was consistently higher than for other local authorities. A similar although less pronounced difference was observed for births of more than 2,500 g., but the converse applies to the lower birth weight infants. In terms of the measure of change (Table III) the reduction in overall mortality is relatively high in the local authorities which are not county boroughs in the north, midlands, and Wales and in the county boroughs of Wales. The same pattern is true for the births of less than 2,501 g. in weight. Generally the larger overall mortality reductions occur in those regions with the higher initial mortality rates, that is, the north, midlands, and South Wales. Thus these data reflect the trends of the international comparisons noted in the introduction. Taking the birth weight and overall mortality trend figures together, it is evident that there exists a much weaker association between the changes in the two factors in the county boroughs than in the other local authorities.

When the data for the standard conurbations were analysed, Greater London and the West Midlands were found to have consistently lower mortality rates than the other conurbations and South East Lancashire consistently higher rates, particularly in the later years. In terms of the trend measure (Table IV) there is a tendency for the larger $\frac{3}{\mathbb{1}}$ reductions to occur in the conurbations with the? higher initial rates. The reduction in Merseyside $\overrightarrow{\vec{s}}$ has been very pronounced, but neighbouring South East Lancashire has shown an exceptionally small $\frac{\mathrm{C}}{0}$ improvement. There is no clear association between $\overline{\bar{c}}$. changes in birth weight distribution and changes in $\overparen{\mathbb{\Phi}}$ mortality in the conurbations. This is perhaps surprising in view of the dominant part played by ${ }^{\circ}$ birth weight in determining the overall mortality $\overrightarrow{0}$ level. In these particular areas complex changes in ethnic, economic, and social structure, affecting $\vec{\sigma}$ other aspects of maternity care in addition to birth $\frac{\widehat{\sigma}}{\widehat{D}}$ weight distribution, have probably tended to $\frac{\mathcal{\rho}}{\mathrm{N}}$ dominate the situation.

So far we have examined only one measure of $\omega$ mortality but it is interesting to look at the general $\vec{c}$ pattern and temporal trends when the overall $\triangle$ mortality data are sub-divided into various grades. 으 More detailed information about neonatal deaths was available for 1963-65 than for the previous years of the decade. For this period the mortality data may be sub-divided into four constituent $\stackrel{\oplus}{+}$ parts-late foetal deaths, deaths within 24 hours, $\vec{\varphi}$ deaths after 24 hours but within 7 days, and deatis after 7 days but within 28 days, and the results obtained in England and Wales for the period 1963-65 are shown in Table VII. Except for the lowest weights, late foetal deaths account for about $55 \%$ of the total mortality within 28 days of birth $\frac{0}{\mathbb{D}}$ and deaths within 7 days account for about $35 \% \propto$ of total mortality. As the birth weight increases, $\overrightarrow{\overrightarrow{0}}$ there is a general tendency for the period of sur- 3 vival of infants dying within 28 days to increase.

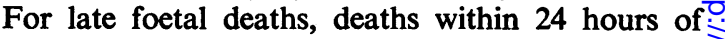
birth, and deaths after 24 hours but within 7 days of birth mortality decreases steadily with increasing? birth weight. For deaths after 7 days but within $28 \frac{5}{3}$ days of birth, the highest mortality occurs in the $1,001-1,500 \mathrm{~g}$. weight group. The general pattern

TABLE VII

MORTALITY PER 1,000 TOTAL BIRTHS IN TERMS OF BIRTH WEIGHT AND TIME OF DEATH, ENGLAND AND WALES, 1963-65

\begin{tabular}{|c|c|c|c|c|c|c|c|c|}
\hline \multirow[b]{2}{*}{ Grade } & \multicolumn{8}{|c|}{ Birth Weight (g.) } \\
\hline & $<1001$ & $\begin{array}{l}1001- \\
1500\end{array}$ & 2000 & $\begin{array}{l}2001- \\
2250\end{array}$ & $\begin{array}{l}2251- \\
2500\end{array}$ & $<2501$ & $\begin{array}{l}\text { Above } \\
2500\end{array}$ & All \\
\hline \multirow{5}{*}{$\begin{array}{l}\text { (1) Late foetal deaths } \\
\text { (2) Within } 24 \text { hr. } \\
\text { (3) } 24 \text { hr-within } 7 \text { days } \\
\text { (4) } 7 \text { days-within } 28 \\
\text { days } \\
\text { (1) }+ \text { (2) } \\
\text { (2) }+ \text { (3) (Early } \\
\text { neonatal) } \\
\text { 1) }+ \text { (2) + (3) } \\
\text { (Perinatal) } \\
\text { (2) }+ \text { (3) + (4) } \\
\text { (1) }+ \text { (2)onatal) } \\
\text { (1) (3) }+ \text { (4) }\end{array}$} & $\begin{array}{l}403 \\
389 \\
104\end{array}$ & $\begin{array}{l}365 \\
195 \\
94.8\end{array}$ & $\begin{array}{r}181 \\
72.5 \\
49.4\end{array}$ & $\begin{array}{l}74.6 \\
27.2 \\
21.8\end{array}$ & $\begin{array}{l}41.2 \\
13.1 \\
11.2\end{array}$ & $\begin{array}{c}128 \\
67.6 \\
34.3\end{array}$ & $\begin{array}{l}7.5 \\
=\end{array}$ & $16 \cdot 3$ \\
\hline & 792 & 560 & $254^{7 \cdot 7}$ & $102^{6 \cdot 1}$ & $\begin{array}{r}4 \cdot 3 \\
54 \cdot 3\end{array}$ & $195^{7.0}$ & 1.4 & 1.8 \\
\hline & 492 & 290 & 122 & $49 \cdot 0$ & $24 \cdot 3$ & 102 & 4.7 & 11.8 \\
\hline & 895 & 655 & 303 & 124 & $65 \cdot 5$ & 230 & $12 \cdot 2$ & 28.0 \\
\hline & $\begin{array}{l}506 \\
910\end{array}$ & $\begin{array}{l}307 \\
673\end{array}$ & $\begin{array}{l}130 \\
311\end{array}$ & $\begin{array}{c}55 \cdot 2 \\
130\end{array}$ & $\begin{array}{l}28.6 \\
69.8\end{array}$ & $\begin{array}{l}109 \\
237\end{array}$ & $\begin{array}{r}6 \cdot 1 \\
13 \cdot 6\end{array}$ & $\begin{array}{l}13.6 \\
29.9\end{array}$ \\
\hline
\end{tabular}




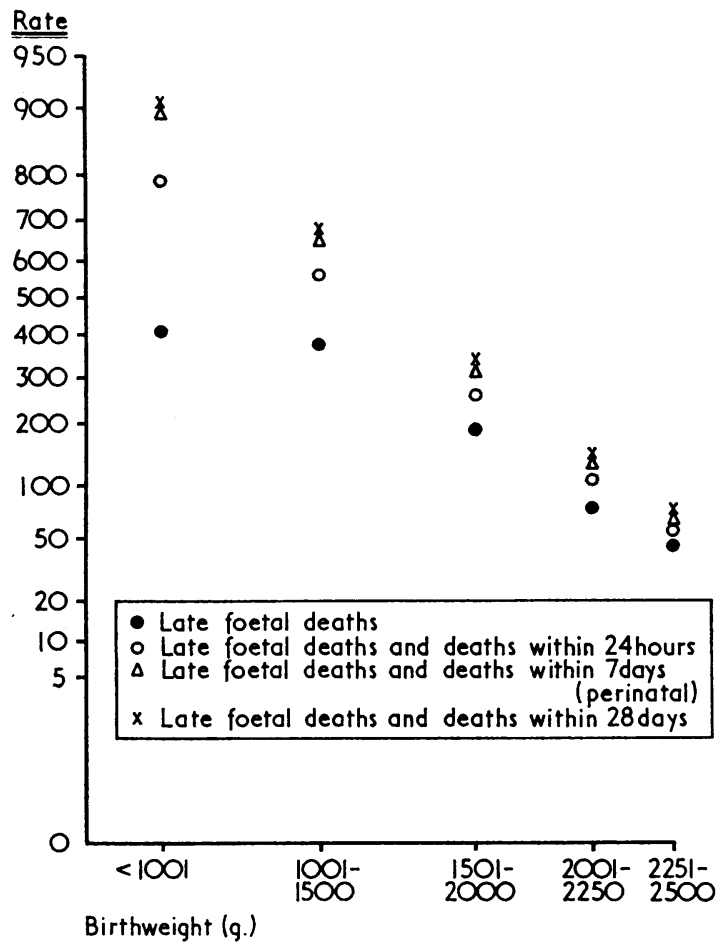

Fig. 2. Mortality per 1,000 total births in terms of birth weight, England and Wales 1956-65.

of the results is illustrated in Fig. 2, where the proportions of late foetal deaths, of late foetal deaths and deaths within 24 hours, of late foetal deaths and deaths within 7 days, and of late foetal deaths and deaths within 28 days are plotted against birth weight using a probit scale. The same pattern was observed in the previous seven years. For all grades of mortality except late foetal deaths alone each set of points lies on a straight line. A similar pattern is found for late foetal deaths alone, except that the point corresponding to late foetal deaths of less than $1,001 \mathrm{~g}$. lies below the line defined by the remaining four points. The deviation of this point may be due to the difficulty of determining the gestational period of a very low weight late foetal death, leading to possible errors in distinguishing between early and late foetal deaths, and for this reason the figure recorded could well be an underestimate. The slopes of these lines increase with increasing grade of mortality.

The secular variations in terms of the various grades of mortality are illustrated in Table VIII, which refers to births of less than $2,501 \mathrm{~g}$. The outstanding fact emerging from this table is that the decrease in overall mortality is due mainly to
TABLE VIII

MORTALITY RATES FOR BIRTHS OF LESS THAN 2,501 g. PER 1,000 TOTAL BIRTHS, ENGLAND AND WALES, 1956-65

\begin{tabular}{|c|c|c|c|}
\hline \multirow{2}{*}{ Year } & \multirow{2}{*}{$\begin{array}{l}\text { Late Foetal } \\
\text { Deaths }\end{array}$} & \multicolumn{2}{|c|}{ Deaths } \\
\hline & & Within $24 \mathrm{hr}$. & $24 \mathrm{hr} .-28$ days \\
\hline $\begin{array}{l}1956 \\
1957 \\
1958 \\
1959 \\
1960 \\
1961 \\
1962 \\
1963 \\
1964 \\
1965\end{array}$ & $\begin{array}{l}149 \\
148 \\
146 \\
142 \\
138 \\
136 \\
132 \\
131 \\
128 \\
124\end{array}$ & $\begin{array}{l}69.5 \\
70.2 \\
69.4 \\
72.8 \\
73.7 \\
72.9 \\
71.9 \\
69.2 \\
69.5 \\
64.0\end{array}$ & $\begin{array}{l}65.6 \\
51.0 \\
52.2 \\
49.1 \\
45.6 \\
47.0 \\
43.8 \\
42.1 \\
41.7 \\
43.0\end{array}$ \\
\hline
\end{tabular}

the reduction in deaths between 24 hours and 28 days and, to a lesser extent, in late foetal deaths. There has been very little reduction between 1956 and 1964 in the recorded mortality of liveborn infants who die before the age of 24 hours.

\section{Mortality Adjusted for BiRTh Weight}

When comparisons are made of mortality rates in different populations, it is possible to adjust the results obtained to eliminate the effect of differences in birth weight. The data available for study in the present analysis are by no means ideal in this respect, since the results are recorded in terms of only a small number of discrete birth weight groups. Nevertheless, standardized mortality indices have been calculated in which the observed mortality rate for the year is expressed as a percentage of the mortality rate which would be expected if the average mortality for that year over the whole country in the various weight groups applied to the particular population. In this way it has been possible to remove the grosser effects of differences in birth weight from comparisons of mortality in different regions and different types of local authority. The changes in the average figures for the three-year periods 1956-58 and 1963-65, which bridge effectively the eight-year interval 1957-64, are illustrated in Fig. 3a (county boroughs) and $3 \mathrm{~b}$ (other local authorities). In the county boroughs the excess of mortality in the northern parts of England not only persists throughout the whole period, but becomes more pronounced with each successive year. The greatest reductions were noted in South Wales and in the Southern regions and the greatest increase in the East and West Ridings and the North Western regions. On the other hand, the relative positions of the other local authorities show very little change.

\section{Discussion}

The analyses described above are based largely 


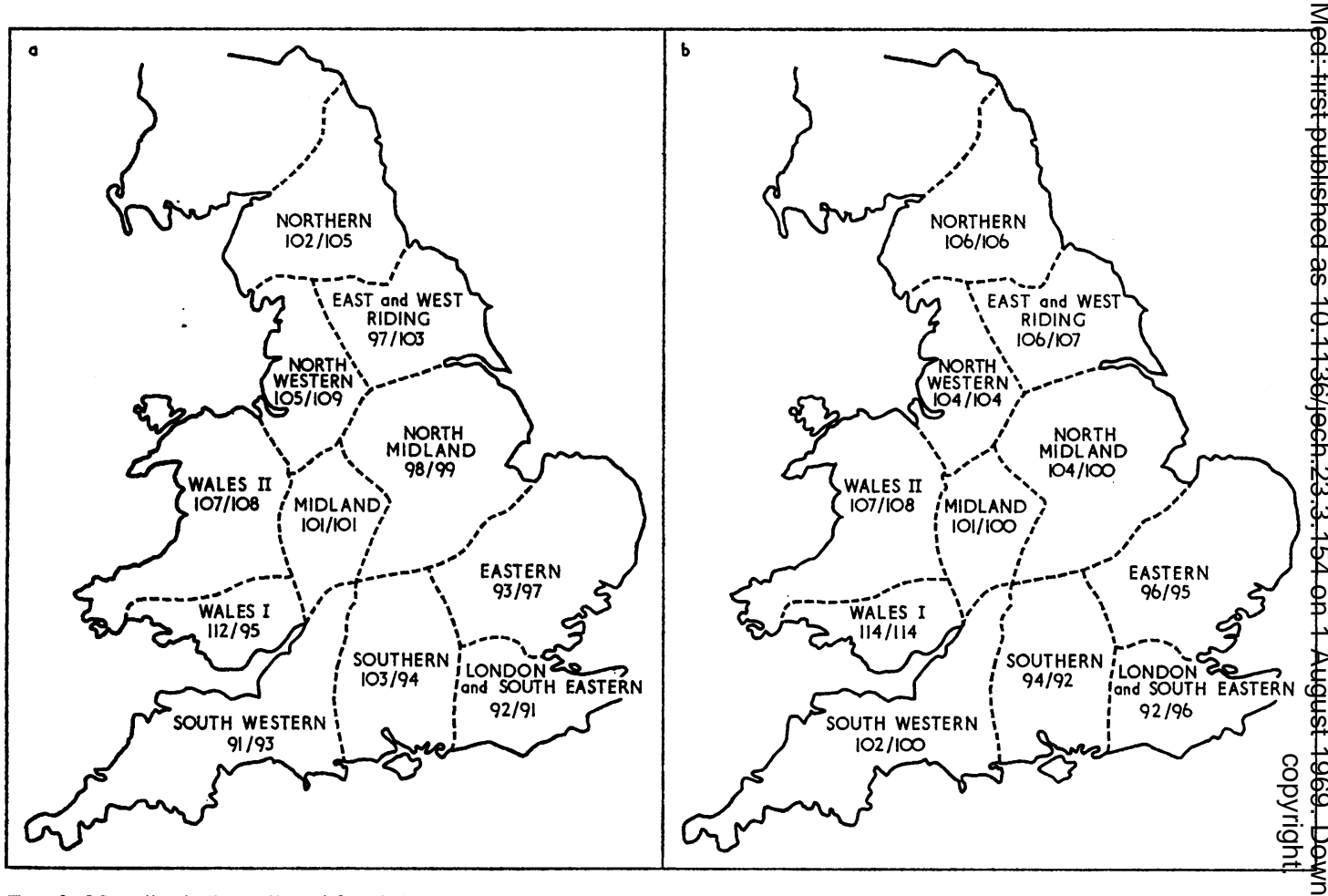

FIo. 3. Mortality indices adjusted for birth weight: (a) county boroughs (including London); (b) all other local authorities. The first figurg refers to $1956-58$ and the second figure to $1963-65$.

upon information returned by the midwife or medical attendant present at the birth to the local authority concerned. Although the number of births taking place in England and Wales was very large (approximately 800,000 ), there is inevitably a considerable range of variation in the quality of the observations. Thus, for confinements taking place at home, methods of weighing new-born infants vary widely in different local authorities and possibly also from time to time in the same local authority. In most areas avoir dupois instruments are used in steps of $4 \mathrm{oz}$. and conversions to the kilogram scale and grouping in 500-g. intervals can produce considerable distortions. On the other hand, in some hospitals metric scales are used. Furthermore, a special study of individual birth weights recorded in the South West of England has shown evidence of a tendency to digit preference in the records of birth weight made both at home and in the hospitals. In spite of these uncertainties, however, it is considered that the steady and consistent reduction in the proportion of low weight births noted in all parts of England and Wales is indicative of a real and significant change in the birth weight distribution.
The classification of mortality in terms of late foetal deaths and deaths within 24 hours is also subject to some uncertainty. The W.H.O. recoms mendation for the registration of live-births includes as evidence of life either breathing or movement or. pulsation. The old definition used by the Registrare General and by most pathologists and obstetriciansin England and Wales was based upon evidence of breathing only. There is no doubt that there is considerable degree of non-uniformity of practices There has probably been an increasing tendency to include among live births some infants of shorter duration of gestation than 28 weeks because the show movement or pulsation which previousl. would not have warranted registration at all. Foor the same reason there is an increasing tendency tou call many mature infants 'liveborn' which previousl 10 would have been notified as late foetal deaths.

The principal finding of the present analysis if the considerable extent to which temporal trends in perinatal and neonatal mortality are associate $\$$ with temporal changes in distribution of birth weight. The steady reduction in mortality in England and Wales between 1956 and 1965 is in large measur a reflection of the corresponding decrease in the 
proportion of low birth weight infants; but it is also very clear from the data that birth weight is not the only operative factor. When the mortalitybirth weight relation is presented using a probit scale, it is apparent that there has been a general improvement year by year at each point in the range of birth weights below 2,501 g. despite the fact that rates of death under 24 hours among the low weight births have remained virtually constant for 10 years. There has also been a marked reduction in both the late foetal death and neonatal death rates for births of above $2,500 \mathrm{~g}$.

The reasons for the decrease in the proportion of low weight births are by no means clear. Factors commonly associated with increased risk of perinatal death include illegitimacy and short stature, advanced parity, advanced age, cigarette smoking, and low socio-economic status of the mother (Baird, 1964; Gibson and McKeown, 1951; Butler and Bonham, 1963). Evidence exists to suggest that these factors are also more or less closely associated with birth weight. For example, both the correlation between maternal height and infant birth weight (Baird, 1962) and the secular increase in the height of mothers (Tanner, 1962) are well established. It is therefore evident that, whatever the causes, the continuing increase in maternal height is likely to be an important reason for the temporal trend towards increased birth weight. In contrast, Illsley and Kincaid (1963) have shown that a mother's performance in pregnancy is in part the result of social and environmental influences which have operated throughout her life and not simply of her socio-economic status at the time of pregnancy.

The changes in birth weight distribution are by no means uniform either in time or between different parts of the country. There was actually a rise in proportion of low birth weight infants between 1956 and 1957 and again between 1960 and 1961. The fall between 1963 and 1964 was at least twice as great as in any other year. The reductions are in general larger in the more rural than in the more urban areas. The main temporal changes occurred one year earlier in the rural areas than in the county boroughs. Even within the standard conurbations there are major variations in the temporal trends. For example, in South East Lancashire there was no consistent difference in the birth weight distribution over the 10-year period, whereas on Merseyside the proportion of low birth weight infants was higher than that in South East Lancashire until 1959 but fell very substantially by 1965 . An explanation of these and the many other interesting variations in the temporal pattern is likely to throw light upon the aetiology of low birth weight. Further studies are now being carried out on the figures for the individual local authorities, which indicate an equally wide variety of patterns of temporal change. There seems little doubt that the substantial alterations which have taken place in the ethnic structure of the populations of the conurbations as a result of immigration, which is perhaps the most dramatic sociological change in England and Wales during the past decade, may explain at least in part some of the apparently anomalous patterns.

The sub-division of the mortality data in terms of late foetal deaths and deaths within 24 hours and between 24 hours and 28 days provides suggestive evidence into the results of the improvements in medical care during the decade. Late foetal deaths have fallen very substantially, from 22.6 per 1,000 total births in 1956 to 15.7 per 1,000 in 1965 . So also have deaths between 24 hours and 28 days, from 65.6 per 1,000 total births in 1956 to 43.0 per 1,000 in 1965 for infants of less than 2,501 g. birth weight. The late foetal death rate has fallen steadily year by year and the improvement in the mortality rate between 24 hours and 28 days has also been reasonably smooth. On the other hand, mortality within 24 hours in the low birth weight groups has shown little change. Clearly, survival during the period immediately after birth is proving to be a more intractable problem than late foetal deaths or survival after 24 hours of life. In 1956, out of every 100 total births of less than 2,501 g. birth weight some $15 \%$ were late foetal deaths, about $7 \%$ died within 24 hours of birth, and $6.5 \%$ died between 24 hours and 28 days. The corresponding figures for 1965 are $12.5 \%, 6.5 \%$, and $4.3 \%$.

On the basis of these results it is possible to make some cautious predictions about future trends. In the first place, it seems likely that the reduction in both the proportion of low birth weight infants and in perinatal mortality will continue for at least a further decade. The presence of substantial differences in both birth weight distribution and mortality between different sections of the population suggests that there is room for a considerable improvement in both factors at least in the less favoured parts of the community. However, experience in the United States (Hunt and Goldstein, 1961) suggests that, as mortality levels fall, the attainment of further reductions becomes progressively more difficult and there may well be a lower limit beyond which further progress is a practical impossibility.

The reductions in mortality year by year during the past decade in England and Wales have been 
by no means uniform. Since the changes which have occurred are of multiple causation and since the factors involved are not clearly understood, the use of standard methods of predicting future patterns, such as linear or polynomial interpolation, should be treated with caution. It is unfortunate that information about many of the factors which may be involved is not generally available in England and Wales. A system of monitoring temporal changes in the ethnic, economic, and sociological structure of the population would be an invaluable aid to the interpretation of epidemiological data, including studies of perinatal mortality.

\section{SUMMARY}

During the decade 1956-65 there has been a marked reduction in perinatal and neonatal mortality in all parts of England and Wales. These changes are accounted for largely but not entirely by a corresponding reduction in the proportion of low weight births. Although the temporal variations in mortality and birth weight are by no means uniform, the consistent differences between the more urban and the more rural areas and between the south and east and the north and west noted in previous studies are present throughout the whole 10-year period. Among the low birth weight infants, the late foetal death rate and the death rate between 24 hours and 28 days have both declined substantially, but there has been little change in the death rate within 24 hours of birth.
Our thanks are due to the Nuffield Provincial Hospitals 3 Trust for a grant which made this study possible, to the Ministry of Health for allowing us access to the L.H.S. 27/1 data, and to Imperial College, University of London for use of their I.B.M. 7090 computer.

\section{REFERENCES}

BAIRD, D. (1962). Environmental and obstetrical factors $\frac{\mathbb{\Phi}}{\overparen{D}}$ in prematurity, with special reference to experience in Aberdeen. Bull. Wld Hlth Org., 26, 291.

- (1964). The epidemiology of prematurity. J. $\vec{O}$ Pediat., 65, 909.

Brimblecombe, F. S. W., Ashford, J. R., and Fryer, $\vec{\omega}$ J. G. (1968). Significance of low birth weight in perinatal mortality. Brit. J. prev. soc. Med., 22, 27.

Butler, N. R., and BonhaM, D. G. (1963). Perinatal în Mortality. Livingstone, Edinburgh.

Duncan, E. H. L., BaIRD, D., and Thomson, A. M. (1952). The causes and prevention of stillbirths and first week deaths. Part I: the evidence of vital statistics.응 J. Obstet. Gynaec. Brit. Emp., 59, 183.

Gibson, J. R., and McKeown, T. (1951). Observations $\vec{D}$ on all births $(23,970)$ in Birmingham in 1947. Brit J. soc. Med., 5, 177, 259.

HuNT, E. P., and Goldstern, S. M. (1961). Trends in $\stackrel{\mathscr{\rho}}{\longrightarrow}$ infant and childhood mortality 1961. Childreios $\overrightarrow{0}$ Bureau Statistical Series, 76.

ILlSLEY, R., and KinCAID, J. C. (1963). Social corretätions of perinatal mortality. In Perinatal Mortalifin, ed. Butler, N. R. and Bonham, D. G., p. 270. Livingstone, Edinburgh.

TANNER, J. M. (1962). Growth at Adolescence, 2nd ed. Blackwell Scientific Publications, Oxford. 